 \\ z Filologii Polskiej i Słowiańskiej
}

Arkadiusz Dudziak

(Uniwersytet Warmińsko-Mazurski w Olsztynie)

Marina Paiunena

(Sankt-Petersburski Uniwersytet Górniczy)

\section{Mikrotoponimy jako sposób kreowania ludowych miejsc kulturowych - podejście antropologii lingwistycznej}

\section{Główne założenia antropologii lingwistycznej}

Przedmiotem zainteresowania antropologów lingwistycznych jest język stosowany przez użytkowników w rzeczywistych kontekstach. Przedstawiciele antropologii lingwistycznej zwracają się ku badaniu praktyki językowej w konkretnych sytuacjach komunikacyjnych. Dla Alessandra Durantiego antropologia językowa to interdyscyplinarna specjalność, w której bada się język jako zasób kulturowy, a mówienie uznaje się za jedną z praktyk kulturowych o fundamentalnej roli w interakcjach społecznych. Dla tego badacza praktyki komunikacyjne konstytuują kulturę w wymiarze codziennego życia (Duranti, 1997).

This is an Open Access article distributed under the terms of the Creative Commons Attribution 3.0 PL License (creativecommons.org/licenses/by/3.0/pl/), which permits redistribution, commercial and non-commercial, provided that the article is properly cited. () The Author(s) 2018. 
Antropologów lingwistycznych interesuje „rola języka w kształtowaniu i odzwierciedlaniu norm kulturowych oraz interakcji społecznych" (Ahearn, 2013, s. 10). Postulują oni, aby pozyskiwać materiał badawczy od respondentów, jak w naukach społecznych, czyli m.in. z wywiadów, które należy traktować jako zdarzenia komunikacyjne. W owych zdarzeniach znaczenia współtworzone są przez różnorodne konteksty (Briggs, 1986, s. 22; Ahearn, 2013, ss. 10-11). Zatem m.in. źródła etnograficzne są tym rodzajem materiału badawczego, na którym antropolodzy lingwistyczni prowadzą analizy praktyk społecznych i językowych. Dlatego jako nazwa specjalności naukowej coraz bardziej popularna (zwłaszcza w Wielkiej Brytanii) staje się również etnografia lingwistyczna (Creese, 2008; Ahearn, 2013, s. 11).

Podobnie jak inni przedstawiciele tej specjalności (Zentella, 1996; Duranti, 1997; Bucholtz \& Hall, 2008), Laura M. Ahearn jest zwolenniczką eklektyzmu metodologicznego. Preferuje ona dialog interdyscyplinarny w badaniu praktyk językowych w rzeczywistych kontaktach społecznych (Ahearn, 2013, s. 11). Swoje podejście badawcze autorka sprowadza do użycia języka jako sposobu działania społecznego i uznaje je za alternatywę perspektywy językowej Noama Chomsky'ego. Interesuje ją bowiem rola języka w kształtowaniu życia społecznego (Ahearn, 2013, s. 12). W koncepcji tej badaczki język nie jest neutralnym instrumentem wykorzystywanym w komunikacji społecznej. Język jest zbiorem praktyk komunikacyjnych ugruntowanych w społeczeństwie. Język pośredniczy w każdej interakcji społecznej (Ahearn, 2013, s. 19).

W przekonaniu tej autorki metody antropologii lingwistycznej zastosowane do autentycznych wypowiedzi językowych umożliwiają badanie szerszych zagadnień społecznych i kulturowych. Ahearn interesują m.in. następujące kwestie: na jakie związki z wartościami kulturowymi i władzą w społeczeństwie wskazują praktyki językowe w różnorodnych sytuacjach komunikacyjnych; w jaki sposób użycie języka odzwierciedla zróżnicowanie kulturowe, etniczne, rasowe, płciowe, wiekowe, majątkowe itp.; jak w języku ujawnia się to, że wszyscy przedstawiciele gatunku ludzkiego są jednakowi jako ludzie, a pod jakimi względami ludzie różnią się językowo i kulturowo; czy (a jeśli tak, to w jaki sposób) formy językowe wpływają na wzorce myślenia i światopoglądy (Ahearn, 2013, s. 21).

Według autorki język jest w swej istocie społeczny; to forma działania społecznego, zasób kulturowy, użytkowany w konkretnych kontekstach społecznych. Ahearn nawiązuje do koncepcji Alessandra Durantiego, który napisał:

antropologia lingwistyczna zostanie przedstawiona w postaci badania języka jako zasobu kulturowego i mówienia jako praktyki kulturowej (Duranti, 1997, s. 2). 
Społeczne konteksty są ściśle związane z użyciami języka. Badaczka konstatuje: „konteksty społeczne i praktyki językowe wzajemnie się współtworzą” (Ahearn, 2013, s. 23). Język jest nie tylko sposobem myślenia, lecz także praktyką kulturową działania społecznego.

Jak stwierdza Duranti:

Traktujemy język nie tylko jako sposób myślenia, ale przede wszystkim jako praktykę kulturalną, tj. formę działania, która zakłada, a jednocześnie powoduje sposoby bycia w świecie. Jedynie poprzez spojrzenie na język w określonym kontekście antropologia językowa może kreatywnie wpływać na pola dotychczasowych badań przy jednoczesnym tworzeniu własnego, unikalnego wkładu w nasze rozumienie tego, co znaczy być człowiekiem (Duranti, 1997, s. 1).

Ahearn sprzeciwia się koncepcjom językoznawczym, w których traktuje się język jak przekaźnik informacji, jak narzędzie do transmisji wcześniej istniejących znaczeń, jak zbiór reguł formalnych. Autorka polemizuje z nastawieniem badawczym typowym dla Ferdynanda de Saussure'a, Noama Chomsky'ego i ich zwolenników. Ich podejście (wypreparowanie langue, czyli abstrakcyjnego zbioru reguł gramatycznych) wyłączało bowiem kontekst w badaniach nad językiem (de Saussure, 1991, s. 42; Silverstein, 2006, s. 276). Tymczasem antropologów lingwistycznych w mniejszym stopniu interesuje badanie systemu form językowych, formalnych właściwości języka. Uważają oni, że aby w pełni zrozumieć sposób działania języka, należy badać jego zastosowania (wymiary mówienia) w rzeczywistych kontekstach (Hanks, 1996; Duranti, 1997, s. 9; Ahearn, 2013, ss. 23-24).

Duranti podkreśla, że w interdyscyplinarnym przedsięwzięciu antropologii językowej traktuje się język jako zbiór praktyk społecznych i akcentuje się rolę mówienia w kształtowaniu społeczeństwa i w interpretacji kultury (Duranti, 1997, s. 21).

Mówienie (uwarunkowane kontekstem) staje się głównym przedmiotem badań antropologów językowych, przez co sytuują się oni w opozycji do tradycji językoznawstwa systemowego, badającego abstrakcyjne modele lingwistyczne i reguły rządzące językiem. W przekonaniu, że używanie języka jest zdeterminowane społecznie i podlega wpływom kulturowym, antropolodzy lingwistyczni uznają, że znajomość abstrakcyjnych reguł gramatyki jest niewystarczająca do opanowania danego języka. Jak stwierdza Ahearn:

Zarówno w podejściu Chomsky'ego, jak i de Saussure’a podstawowym lub nawet jedynym przedmiotem zainteresowania językoznawstwa jest abstrakcyjna zna- 
jomość systemu języka (kompetencja lub langue), podczas gdy wykonanie, czyli parole, pozostaje nieistotne. [...] Antropolodzy lingwistyczni odrzucają przeto wprowadzone przez Chomsky'ego i de Saussure’a rozróżnienie kompetencji/ langue i wykonania/parole (Ahearn, 2013, ss. 24-25).

W aspekcie metodologicznym antropologia językowa dotyczy odczytania i zrozumienia tekstu (wytworu językowego realizowanego w akcie komunikacji) na poziomie współistnienia (korespondowania) z faktami kultury, co wymaga umieszczenia wypowiedzi w kontekście kulturowym (na temat poziomów odczytania tekstu i typów kontekstów - zob. van Dijk, 1980; Filar \& Piekarczyk, 2006, ss. 21-33; Chruszczewski, 2011, ss. 215-219). Antropologów lingwistycznych interesuje zależność pomiędzy kulturą, społecznością i tekstami, które generuje dana zbiorowość. Dominanta elementu kulturowego nad językowym odróżnia metodologicznie antropologię lingwistyczną od lingwistyki kulturowej oraz lingwistyki antropologicznej (Anusiewicz, 1994, s. 10, 1995, s. 11; Chruszczewski, 2011, ss. 73-78). Ukierunkowanie uwagi badawczej na szerokim kontekście kulturowym (na znaczeniu i procesie jego budowy w kulturze; na „kulturowym zanurzeniu tekstów”), a nie na myśleniu, nie na zjawisku odzwierciedlania w języku (zwłaszcza w leksyce specjalistycznej) antropologicznego procesu rozwoju rozumowania i zdobywania wiedzy, różnicuje antropologię językową od tzw. antropolingwistyki (Sękowska, 2000, ss. 11-20; Griniewicz, Zaniewski, Skopiuk, \& Sorokina, 2009, ss. 9-10, 15-18, 22-24, 109; Chruszczewski, 2011, ss. 79, 225-228).

\section{"Cultural constructions of place" w antropologii lingwistycznej}

Jednym z przedstawicieli antropologii językowej jest Keith Basso, który w okresie od 7 czerwca do 10 października 1982 roku zajmował się gromadzeniem materiału empirycznego dotyczącego językowej i kulturowej kreatywności Apaczów Zachodnich w zakresie tzw. „tworzenia miejsc”, czyli nadawania obiektom przestrzennym określonych wartości kulturowych (Basso, 1996a, s. 89). Apacze nadawali własne, oryginalne nazwy różnorodnym obiektom topograficznym oraz stosowali w codziennych rozmowach nawiązania do owych nazw i związanych z nimi historii. Te wzmianki, określane jako „mówienie nazwami”, a także jako „cultural constructions of geographical realities”, „cultural constructions of place” (Basso, 1996a, s. 53), stawały się okazją do 
kształtowania świadomości aksjologicznej i tożsamości kulturowej poprzez manifestowanie wartości etycznych i moralnych, waloryzowanie relacji międzyludzkich i stosunku do środowiska fizycznego (Ahearn, 2013, ss. 27-28). Według Bassa zadaniem antropologii językowej jest badanie symbolicznych kontekstów relacji pomiędzy człowiekiem a jego otoczeniem:

Życie społeczne jest wszędzie realizowane poprzez wymianę form symbolicznych. Od antropologów należy oczekiwać regularnego raportowania na temat odmienności znaczeń, nadawanych przez mężczyznę i kobietę cechom ich naturalnego otoczenia (Basso, 1996a, s. 53).

Basso stwierdził:

Większość plemion Indian amerykańskich obejmują "przestrzenne koncepcje historii«, w których miejsca i ich nazwy - i wszystko to, co mogą symbolizować mają podstawowe znaczenie. Dla indiańskich mężczyzn i kobiet przeszłość osadza się w rysach ziemi - w kanionach i jeziorach, górach, skałach, pustyniach - łącznie nadających ich ziemi wiele form znaczeniowych, które kształtują ich życie i sposoby myślenia. Znajomość miejsc jest zatem ściśle związana z poznaniem siebie, orientowaniem się w większym planie rzeczy, w tym we własnej wspólnocie i zapewnianiu poczucia tożsamości, świadomości, kim jest dana osoba (Basso, 1996b, s. 34).

W dalszej części artykułu przedstawimy przykłady zachowań językowych przedstawicieli polskiej kultury ludowej, respondentów (natywnych użytkowników badanego języka, pomagających badaczowi w terenie w uzyskiwaniu materiału empirycznego - Chruszczewski, 2011, s. 105) z okolic Augustowa, których działania językowe (tworzenie nazw kulturowych, nazw małych obiektów) potwierdzają antropologiczne zjawisko konstytuowania miejsc, opisane przez Bassa.

\section{Nazewnictwo jako antropologiczny sposób przekształcania przestrzeni natury w miejsce kultury \\ - na przykładzie ludowych przekazów ustnych mieszkańców powiatu augustowskiego}

Materiał językowy pozyskano od 150 respondentów w trakcie wywiadów terenowych przeprowadzonych w latach 1994-2006 (Drowdwiłło-Batura, 2007, s. 109 - lokalizację wybranych wypowiedzi w tekście publikacji etnograficznej oznaczamy poniżej numerami stron). 
[1] Jak król August przejeżdżał, ten, co fundował kościół w Szczebrze, to nadzielał działki dla ludzi. Była tu taka górka Stożek i na tym Stożku un tam sobie upodobał, że sie zatrzyma. Byli już tu osadnicy i któraś pani nagotowała barszczu z buraków, i częstowała tym barszczem, i stąd nazwa [Barszczowa Góra, gm. Nowinka] (s. 110).

[2] Uroczysko Paproć u podnóża wysokiej góry, z której wytryska źródło i płynie do rzeki Wołkuszanki, bierze nazwę stąd, że w podmokłych miejscach rosło tu dużo paproci (s. 110).

[3] Niedaleko od rzeki Szczeberki jest miejsce zwane Gajdowe Bagienko. Nazwa wzięła się stąd, że żył dawno temu biedak Gajda, który zmuszony był kraść z pól. Ludzie o tym wiedzieli, ale dwóch młodzików umówiło się, by Gajdę przestraszyć. Ten zrozumiał, że jego przykra sytuacja wydała się, i ze zmartwienia powiesił się na drzewie, rosnącym na tym bagienku (s. 110).

[4] Nad brzegiem Biebrzy wznosi się dziwna Pobojna Góra, w środku zapadnięta, po bokach na szczycie są wały. Opowiada się, że był tam gród, który się zapadł. Inni mówią, że była tu wielka bitwa i dużo trupów na szczycie pozostało. Te trupy przysypano piaskiem i jak ciała rozłożyły się, środek góry zapadł się. Od tego poboju jest nazwa góry (s. 110).

[5] Jeden pan szukał miejsca na siedzibę i chodził bardzo długo. I kiedy znalazł odpowiednie miejsce, wieś, którą założył, nazwał Długie (s. 110).

[6] Między Dulkowszczyzną a Jacznikami jest grobla, przejście wśród bagien zwane Zielona Pończocha, bo wielu widziało w tym miejscu zieloną pończochę (s. 110).

[7] Jedna góra nazywa się tu Kościólek. Kiedyś stał tu kościół. Dookoła były jakieś wały i było z nich wejście pod ziemię jakieś głębokie. Jeden tu orał i wyorał wielki klucz (s. 110).

[8] Opowiadała babka, że nazwa Gruszki wzięła się stąd, że w dawnych czasach przebywał w puszczy królewskiej osocznik. Kiedyś przyśniło się mu, że spotka go szczęście, tylko musi je odszukać. Odszedł z rana osocznik ze swej budy i wędrował po puszczy. W wieczór zmęczony zasnął pod jakimś drzewem. Zbudził się o świcie i zobaczył, że spał pod wielką dziką gruszą, niedaleko budy bartnika. $Z$ budy wyszła piękna córka bartnika. Osocznik zobaczył ją i zakochał się od pierwszego wejrzenia, i tak pod gruszą znalazł swoje szczęście. Wieś, którą założył, nazwał Gruszkami (s. 111).

[9] Król, będąc na polowaniu w naszej puszczy, ugrzązł w bagnie ze świtą i zrozpaczony zawołał: „- ale tu hrusko!” [znaczy grząsko]. Stąd pochodzi 
nazwa wsi nad bagnistymi łąkami rzeki Jastrzębianki rozłożonej [Hruskie, gm. Sztabin] (s. 111).

[10] Las Ostrzałek ma nazwę od tego, że w każdej wojnie bywał ostrzelany (s. 111).

[11a] Uroczysko Księżno przy szosie grodzieńskiej wzięło nazwę stąd, że przed scaleniem gruntów obszar ten należał do plebana lipskiego, który podzielił go na osiem działek po pół hektara i nadał osadnikom. Że z ręki księdza ta ziemia, to miejsce nazwano Księżno (s. 111).

[11b] Las między Hruskim a Jasionowem na północnej stronie szosy nazywa się Laskami Wojskowymi, jest tam coś jakby strzelnica. Niemcy w lipcu 1944 roku okopali się tam i były walki (s. 111).

[12] Wieś ma nazwę od dużej ilości ryb - jazi, w rzece Jaziewiance [Jaziewo, gm. Sztabin] (s. 111).

[13a] Ma nazwę od imienia księcia Poniatowskiego [Józefowo nad rzeką Szczeberką, gm. Nowinka]. Jedno z pól nazywa się stąd Poniatowizna [łąki na granicy z Nowym Gatnem] (s. 111).

[13b] Księża Linia - droga od Szczebry do Józefowa nazywa się od tego, że jeździł nią często ksiądz ze Szczebry na karty do swego przyjaciela (s. 111).

[14] Tam mieszkali pracownicy z dworu w Olszance. Nazwa wzięła się od czasów nadawania ziemi pana. Dwóch czy trzech tu było gospodarzy, reszta służba dworska. Pan kawałek ziemi dawał i oni stawiali domki [Juryzdyka, gm. Nowinka] (s. 111).

[15a] Ma nazwę stąd, że ponad 150 lat temu [w połowie XIX wieku] ludzie wykopali łącznik między jeziorami Blizienko i Tobołowo, i nazwali go Kopanką. Od niej poszła nazwa wsi [Kopanica, gm. Nowinka] (s. 111).

[15b] Las Sówki ma nazwę od szkodnika sówki-chojnówki, co to po pierwszej wojnie rozlazła się, bo Niemcy po wycince nie zabrali drzewa i był wyląg owadów (s. 112).

[16] Starzy ludzie mówili, że Chreptowicz, gdy król był ranny w walce, zgiął „hreb”, czyli grzbiet i król wszedł po nim na konia. Za to w nagrodę dostał tyle ziemi, ile objechał konno w ciągu doby. W czasie tego objeżdżania Chreptowicz zaznaczał te granice kopcami, stąd do tej pory są tu kopce graniczne i od nich nazwa wsi [Kopiec, gm. Sztabin] (s. 112).

[17] Mogiłkowa Góra - wzniesienie nad jeziorem Krzewa Duża ma nazwę od mogiłek wioskowych. Najstarsi ludzie pamiętali, że stały tam drewniane krzyże z datami dziewiętnastowiecznymi (s. 112). 
[18] Góra Mohlicy ma nazwę stąd, że w czasie zarazy dżumy grzebano tam zmarłych (s. 112).

[19] Wieś w dawnych czasach nazywała się Łabędzin. Na rzece Lebiedziance zawsze były te ptaki [Lebiedzin, gm. Sztabin] (s. 112).

[20] Uroczysko Chlebownik ma nazwę stąd, że kobiety na tym grądzie w czasie powstania styczniowego piekły chleb, po który przychodzili partyzanci $\mathrm{z}$ różnych oddziałów (s. 112).

[21] Uroczysko Czerwony Ług bierze się stąd, że była tu wielka bitwa między Krzyżakami a Jadźwingami. Polało się w niej tyle krwi, że powstał z niej ług - jezioro, które po wyschnięciu było czerwone (s. 112).

[22] Droga między Macharcami a Frąckami, odchodząca od szosy do Strzelcowizny, nazywa się Magdzina Droga. Za cara, przed pierwszą wojną, jeździł tędy oficer rosyjski do dziewczyny, mającej na imię Magda i mieszkającej w Strzelcowiźnie (s. 112).

[23] Na górze zwanej Kościótek w dawnych wiekach stał kościół. Jeszcze teraz wyorują rolnicy, którzy mają tam pola, kości po cmentarzu i monety. Najstarsi pamiętali krzyż drewniany, który stał na wzgórzu. Dookoła wzniesienia były resztki jakiegoś wału i w jednym miejscu była w nim dziura - zejście gdzieści pod ziemię (s. 112).

[24a] Uroczysko Cygański Łuzak jest od krzyża, co stoi przy drodze na Jastrzębną, lasem do bagna. Tam stały kiedyś tabory Cyganów. Widziałam je jeszcze w latach pięćdziesiątych [XX wieku] (s. 112).

[24b] Uroczysko Panieński Grób zwane też Dziewiczym Grobem miało nazwę stąd, że jak panna urodziła dziecko, cała ludność prowadziła ją w to miejsce i ona tam tonęła w bagnie. Wtedy taką dziewczynę grzebano na cmentarzu. Inna wersja tej smutnej historii twierdzi, że dziewczynę kamieniowano. Potem, żeby odpędzać strachy, zawieszano obraz na sośnie. Ludzie idący na odpust do Krasnegoboru odpoczywali tam i drzewo nazywali Wielka Sosna (s. 113).

[25] Od Barszczowej Góry pod Olszankę jest Diabelska Góra, już pod folwark należała. Ona była mocno gliniasta i droga przez nią była mocno błotna, więc ludzie jak tam jeździli mówili, że diabeł tam w to błoto wtochlał i ciężko było wyjechać (s. 113).

[26] Jak organizowano Gabowe Grądy i Bór, ścinano drzewa i spławiano je rzeką, znaczy Kolniczanką. Później na łące w kierunku na Obuchowiznę 
w czasie pierwszej wojny pochowano zabitego kozaka. Teraz nazywa się łąkami $\mathrm{Na} \mathrm{Kozaku} \mathrm{(s.} \mathrm{113).}$

[27] Jezioro Pobojno, dawniej nazywane Pobitno, od wielkiej bitwy, w której padło wiele trupów. To chyba było za Jaćwingów (s. 113).

[28] Część wsi - Chapowo - ma nazwę stąd, że ziemie na place mieli tu ludzie z Dubowa i z Zielonego, i oni chapali tę ziemię, bo nie mieli gdzie się budować. Nazywano na nich chapowiaki [Podnowinka, gm. Nowinka] (s. 113).

[29] Nazwa pochodzi stąd, że kiedyś polował tu król z orszakiem i wpadł w dziurę. I nie mógł z tej dziury sam wyleźć, i musiał prosić poddanych o pomoc, i poniżył się tą prośbą [Ponizie, gm. Augustów] (s. 113).

[30a] Sadzono tu rzepę, stąd nazwa [Rzepiski, gm. Augustów] (s. 113).

[30b] Pola pod Komaszówką mają nazwę Pieńki. Kiedyś służba z dworu w Kolnicy miała w Rzepiskach działki, a dalej były nieużytki, których nikt nie chciał uprawiać. Wycięto więc olszyny i zarośla, powstało pole i od pozostałych pni poszła nazwa (s. 113).

[31] Na Dworczysku miał być duży dwór, który zapadł się pod ziemię. Teraz fale jeziora Sajno wypłukują tu z brzegu dziwne przedmioty (s. 113).

[32a] Podserski Las dawniej nazywano Siulaki [Jastrzębie]. Jeszcze przed drugą wojną na Siulakach, gdzie teraz las, rosła gryka. Nazwa Siulaki pochodzi od familii Siulewskich [Serski Las, gm. Płaska] (s. 113).

[32b] Serski Las - to powiedali ludzie, że tam był las z wierzby dziuplastej, i tam mieszkali szerszenie, i od tego powstała nazwa Szerszki Las (s. 113).

[33] Na północ od szosy grodzieńskiej najwyższe wzniesienie nazywa się Zamkową Górą. U jej podnóża są trzy ługi [stawy], obecnie zarośnięte, jakby chroniły dostępu do tej góry.

[34a] Ma nazwę stąd, że polował tu król z sokołami [Sokolne nad Szczeberką, gm. Nowinka] (s. 113).

[34b] Żyd miał objawienie Matki Boskiej na dębie. Z tego dębu zrobiono potem krzyż. Niemcy dowiedzieli się o tym, ścięli ten krzyż i chcieli go spławić rzeką, ale wracał. Ludzie uwierzyli, że to Święte Miejsce (s. 114).

[35] Czerwone Bagno pod Strzelcowizną stąd ma nazwę, że tak zawzięcie powstańcy tam walczyli, że bagno czerwone było od krwi (s. 114).

[36a] Młynisko - nad Rospudą była zabudowa gajowego - dom, stodoła, chlew, młyna już nie było, młyn był w Chodorkach [Szczebarka, gm. Nowinka] (s. 114). 
[36b] Sztylowy Grąd - wyspa niedaleko od Młyniska, naokoło jest bagno. Nazwa od sztylisk [stylisk] do narzędzi, bo dobre drzewo tam było [Szczebarka, gm. Nowinka] (s. 114).

[37a] Ruska Kładka - oddział leśny 273 - w czasie okupacji sowieckiej przez łąki i Rospudę około $2 \mathrm{~km}$ zrobiona była z żerdzi kładka, szła do Szczebry. Żołnierze [pogranicznicy] chodzili po niej [Topiłówka, gm. Augustów] (s. 114).

[37b] Żelazny Mostek - oddział leśny 211 - od Młyniska w prawo, niedaleko Rospudy. Teraz nie ma tam mostku, był przed wojną, bo był tam wykopany rów [Topiłówka, gm. Augustów] (s. 114).

[38] Sołojewszczyzna - dawniej wieś, obecnie część Wołkusza, ma stąd nazwę, że dawno temu nocowała w tutejszym dworze królowa i nie mogła, i nie chciała spać, bo całą noc pięknie śpiewały słowiki. Rano do swojego kanclerza powiedziała: tę okolicę nazwiecie Sołowiewszczyna [rosyjskie sołowiej to 'słowik'], bo tyle tu słowików. Potem uproszczono nazwę (s. 114).

[39] Bo z dwóch stron wsi były wrota, przy których stała straż. Były tu lasy niesamowite, banda w nich grasowała i ludzie ginęli, stąd ta nazwa [Wrotki, gm. Sztabin] (s. 114).

[40] Obok wsi znachodzi się duży ług, obecnie zarośnięty. W dawnych wiekach było to jezioro i mieszkała w nim zaklęta w żabę piękna królewna. W dni wiosenne wypływała jako pół żaba, pół człowiek i ładnie śpiewała. Pewnego razu był tu na polowaniu królewicz i jak ujrzał ją, zdjął z niej czary, zabrał na konia i odjechał. Ludzie słyszeli w tym śpiewie tylko rechot. Teraz każdej wiosny też rozlega się taki rechot. Od tego wzięła nazwę wieś [Żabickie, gm. Lipsk] (ss. 114-115).

[41] W uroczysku Królowa Woda król August poił w źródełku konie, a obok w uroczysku Okół kazał wykopać w ziemi stół i siedzenie. Ziemię z okopu rzucono do środka, wyrównano ją i siedziano ze spuszczonymi nogami jak przy stole. Jeszcze teraz są tego ślady (s. 115).

\section{Podsumowanie}

Zapewne byłoby to cenne poznawczo, aby każdą z przytoczonych wypowiedzi natywnych poddać osobnej i wnikliwej analizie w aspektach antropologiczno-tanatologicznych (tematyka niektórych wypowiedzi dotyczy śmierci, tragicznych zgonów, samobójstw, osób zmarłych, grobów, mogił etc.), antropo- 
logiczno-semiotycznych i antropologiczno-pragmatycznych, a także w aspektach językowych ekwiwalentów grupowego myślenia mityczno-magicznego, tożsamości kulturowej w wymiarze etniczności, antropocentryzmu lingwistycznego. Jednak zadanie takie wykracza poza objętość artykułu.

Zatem w niniejszym opracowaniu skupimy uwagę jedynie na ogólnym kontekście kulturowym. W przytoczonych językowych wypowiedziach etnicznych funkcjonuje uniwersalny eschatologiczny motyw kulturowy „Przekształcania Chaosu w Kosmos” (Mieletinski, 1981, ss. 251-263; Bettelheim, 1985, s. 150; Eliade, 1993, ss. 361-367; Trzciński, 2006, ss. 128-132). Zawierają one symbolikę „Centrum Świata” - najczęściej symbolikę mikrokosmosu sacrum; symbolikę drzewa: rytualnego, mitycznego, kosmologicznego odradzania się kosmosu; życia; mocy sakralnej; archaicznych tradycji doznawania wartości sakralnych; prawzorów objawienia rzeczywistości pozaludzkiej; archaicznych miejsc świętych; siedzib bóstwa; boskiego macierzyństwa; dusz zmarłych pragnących powrotu do życia; opieki bogini nad duszami; krzyża (Eliade, 1993, ss. 226-230, 259-267, 273-276, 282).

Nieprzypadkowo tematyka wypowiedzi dotyczy przestrzeni odludnych, środowiska obcego, opuszczonego, co - w aspekcie antropologicznym odpowiada nastrojom wyobcowania, zagubienia, trwogi, egzystencjalnego lęku (Fromm, 1994, s. 20). Respondenci kreują nazwy uroczysk. W kulturze słowiańskiej są to obszary w głębi puszczy związane z kultem bóstwa lub kultem przodków; siedziby złych duchów; tajemnicze, odludne pustkowia (Szymczak, 1981, s. 616). W cytowanych wypowiedziach etnicznych nadawanie nazw tego rodzaju przestrzeniom i przekształcanie ich w miejsca kulturowe (Eliade, 1993, ss. 354-361), tj. w miejsca pamięci, miejsca grupowej tożsamości, miejsca nobilitowane lokalną historią lub legendą, miejsca nobilitowane elementami sacrum - odpowiada kulturowemu motywowi „Renovatio”, czyli odrodzenia, odnowy poprzez działania magiczne, identyfikacje z obiektem kultu lub bohaterem kulturowym, rytualne zmiany nazwy w celu zmylenia demonów (Eliade, 1993, s. 390; Jung, 1993, ss. 127, 143, 144).

Zgodnie z klasyfikacją genologiczną polskiego folkloru w ujęciu Jerzego Bartmińskiego, zaprezentowane teksty należy zaliczyć do gatunku opowieści wierzeniowych i wspomnieniowych (Bartmiński \& Niebrzegowska-Bartmińska, 2012, s. 140). Zacytowany materiał językowy wypowiedzi ludowych dotyczy takich kategorii nazewnictwa jak toponimy, w tym mikrotoponimy. Te formacje leksykalne w owych tekstach etnicznych pełnią antropologiczną funkcję reorganizacji przestrzeni w miejsce, rozumiane jako kategoria kulturowa. 
Autentyczne nazwy miejscowe i terenowe zostały użyte przez respondentów w celu lokalizacji opowiadanych zdarzeń i opisywanych stanów rzeczy w konkretnej przestrzeni najbliższego otoczenia, które dobrze znają i z którym się identyfikują. Toponimiczne i mikrotoponimiczne zabiegi językowe autorów wypowiedzi służą wartościowaniu środowiska (utożsamianiu się z nim), jak również uwiarygodnieniu wypowiedzi poprzez dokładną lokalizację. Dzięki temu uzyskuje się językowy efekt wprowadzania w miejscowe realia, zdarzenia; przemawiania do wyobraźni; wytwarzania klimatu swojskości, bliskości.

W folklorystycznych mikrotoponimach natywnych użytkowników języka z okolic Augustowa występuje charakterystyczna językowa tendencja gwarowa do tworzenia form emocjonalnych, deminutywno-ekspresywnych (na temat słowotwórczych sygnałów wartościowania w języku folkloru: Burska-Ratajczyk, 2013, s. 192): „Kościółek”, „Mogiłkowa Góra [...] ma nazwę od mogiłek wioskowych”, „Cygańska Górka”, „Wólka Karwowska”, „Gajdowe Bagienko”. Uznaje się takie formacje za młodsze typy onomastyczne (Urbańczyk, 1992, s. 221), co może świadczyć o tym, że paradygmat etniczności jest wciąż żywy na badanym terenie i kolejne pokolenia użytkowników języka przekształcają przestrzeń lokalną w miejsce kulturowe, rozumiane jako „Centrum Świata” (potwierdza to ankieterka stwierdzająca, że młodsze pokolenie przejmuje zwyczaj kreowania opowieści ludowych - Drowdwiłło-Batura, 2007, s. 144).

Użytkowane przez respondentów nazwy kulturowe można zbiorczo zestawić w określonych typach formacji onomastycznych:

1. Ojkonimy - nazwy miejscowe osad ludzkich (wsi, przysiółków): Łabędzin, Chapowo, „Na Dworczysku”, „Młynisko”, „Sztylowy Grąd”, „Sołojewszczyzna”, „Sołowiewszczyna”, „Bobra Chata”, „Na Prusakowiźnie”, „Na Dąbku”, „Przy Kapliczce Borowej”, „W dworku w Rafałówkach”, „w Tartaku”, „za kapliczką na Świerniskach, „za grądem”, „Na Barakach”, „W Wielkiej Parowie”, „część Kunichy nazywa się Bojary”, „leśniczówka Okop”, „za dworem, gdzie była stodoła, w kierunku na Juryzdykę, „Tam, gdzie był dwór i park [...] w alei lipowej [wieś Pruska gm. Bargłów]”, „Na Zielonym, tam gdzie [...] była karczma”, „Pod Pieckiem, którzy niektórzy nazywają Pieczyskiem”, „na Barakach”, „Chapowo”, „Na Barakach”;

2. Mikrotoponimy:

- nazwy pól: „koło pola Reńka Wasilewskich na Wądołach były doły na kartofle”, „Pieńki”, „do wądołów na kartofle”, „Lipówka albo Lipowka”;

- nazwy łąk: „Poniatowizna”, „Na Kozaku”, „Przy Pieciówce”, „Piecia”; 
- nazwy uroczysk: „Uroczysko Paproć”, „Uroczysko Księżno”, „Uroczysko Chlebownik”, „Uroczysko Czerwony Ług”, „Uroczysko Cygański Łuzak”, „Uroczysko Panieński Grób, zwane też Dziewiczy Grób”, „W uroczysku Królowa Woda”, „w uroczysku Okól”, „na uroczysku Krzyżyki”, „Na Uroczysku Kalucha”, „na uroczysko Kożuchowo”, „W uroczysku Koleśniki”, „w uroczysku Derdy”, „W Uroczysku Pańkowskie”, „W uroczysku Stara Ruda”, „na uroczysku Okrągły Borek”;

- nazwy bagien, ługów, mokradeł: „Gajdowe Bagienko”, „Czerwone Bagno”, „Gaj”, „Sucze Bagno”, „przy bagnie Kaluzie”, „przy bagnie Musarz”, „Olszowe Bagno";

- nazwy dróg polnych, ścieżek, grobli, kładek, mostków: „Zielona Pończocha” [grobla, przejście wśród bagien], „Księża Linia” [droga leśna], „Magdzina Droga”, „Ruska Kładka” [kładka przez łąki i Rospudę], „Niedaleko Lipowskiej Drogi”, „z Budową Drogą”, „Pod Rybalnym Mostem”, „na grobli zwanej Zieloną Pończochą”, „Na mostku na Kalnej”, ,przy mostku na Kolniczance”, „na przepuście na drodze z Karpy do Bargłówki”, „na drodze zwanej Grobelka pomiędzy Czarniawem a Bartną Górą”, „przy drodze na Ostry Róg”, „Kilkadziesiąt metrów od krzyżówki Kopiec - Wrotki, Huta - Tajno był mostek na bagnie”, „drogą do końca Kuriank, jeszcze przed rozwidleniem na Skieblewo od strony Starożyńc, gdzie pierwsza górka”, „jak schodzić w dół z Czerkiesów do Jeziork, to stała przy drodze brzoza i wisiała przy niej kapliczka z Matką Boską”, „Na Kalekach pod Krasnoborki, za Księdza Grodzią”, „Na krzyżówce między Dulkowszczyzną a Kuriankami, tam gdzie krzyż metalowy”, „Między Białobrzegami a gliniankami, na starej sośnie wisi kapliczka w dziupli”, „Za mostem na Strzelcowiznę”, ,jak jest przepust i rów do Zalewianki”, ,jak jechać z Kopanicy do Monkiń, w dołku”, „przez mostek na Prusce”, „na moście na Perstuńce”, „Koło Żelaznego Mostku”, „Przy drodze z Jamin na Wrotki, w miejscu zwanym Łubianka, stoi figura Matki Boskiej”;

3. Oronimy - nazwy gór: „górka Stożek”, „Pobojna Góra”, „góra Kościółek”, „Mogiłkowa Góra”, „Góra Mohlicy”, „Kościółek”, „Diabelska Góra”, „Zamkową Górą”, „Babia Góra”, „wzgórze zwane Borsuki”, „Na Lipowej Górze”, „U podnóża Kościółkowej Góry”, „Góra między Bargłowem Dwornym a Nettą Folwark - Bocianówka”, „Bartną Górą”, „w miejscu zwanym Bocianówką”, „miejsce zwane Łysą Górą”, „na Cygańskiej Górce”, „Na Brodnej Górze”, „Na 
Łysej Górze”, „Na Górze Masłowskiego”, „na Stromych Górkach”. Znaczna frekwencja oronimów w badanym materiale jest zjawiskiem niezwykle interesującym. W onomastyce funkcjonowało bowiem przekonanie, że w Polsce nie poświęcano zbyt wiele uwagi oronimom, jako że w kraju mało górzystym ludność rolnicza nie interesowała się wzniesieniami ze względu na brak znaczenia gospodarczego (Urbańczyk, 1992, s. 237).

4. Drymonimy - nazwy lasów: „las Ostrzałek”, „Laski Wojskowe”, „Las Sówki”, „Podserski Las dawniej nazywano Siulaki [Jastrzębie]”, „Szerski Las”, „Święte Miejsce”, „młody las [...] Okopy”, „na Sztukach”, „w olszynce pod Wolnym”, „W Neckim Borku”;

5. Hydronimy - nazwy rzek, jezior: „Kopanka” [łącznik między jeziorami], „Jezioro Pobojno, dawniej nazywane Pobitno”, „Północna zatoka jeziora Serwy nazywa się Zdrojki”, „Topiłek” [Ślepe Jeziorko k/Mikaszówki w gm. Płaska], „do janowskiego rowu - Zalewianki”, „koło Ślepego Jeziorka”, „W Ślepym Jeziorku w Mikaszówce”, „na Rybalni, tam gdzie koniec Stawu Sajenek”, „koło Młyniska w Ślepym Jeziorku”, „nad rzeczką, która nazywa się Słuczka”, „Na Barwiku”.

W zgromadzonym materiale językowym wypowiedzi ludowych zwraca uwagę bogactwo mikrotoponimów, nazw małych obiektów fizjograficznych, takich jak nazwy własne przysiółków, nazwy części wsi, części jezior i lasów, nazwy pól, dróg czy cieków wodnych. Pozwala to wnioskować, że w kulturze ludowej mieszkańców puszcz z okolic Augustowa zjawisko kulturowego przekształcania przestrzeni w „miejsce” (jako symboliczną formę antropologicznego ustanawiania „Centrum Świata”) może dotyczyć właściwie każdego obiektu topograficznego.

O funkcji zaklęć w tekstach mitycznych i baśniowych oraz ich oddziaływaniu w psychologicznych procesach odnajdywania „miejsca”, czyli poczucia bezpieczeństwa w świecie, wewnętrznej harmonii psychicznej, pisał Bruno Bettelheim (Bettelheim, 1975, s. 10). W takim kontekście nadawanie obiektom przestrzeni nazw etnicznych odgrywa antropologiczną rolę sui generis zaklęć magicznych, stosowanych w celu opanowania natury i podporządkowania jej kulturze (przekształcania Chaosu w Kosmos).

Zaprezentowany materiał empiryczny w postaci wypowiedzi natywnych użytkowników języka potwierdza koncepcję Piotra P. Chruszczewskiego, który skonstatował: „Społeczności dyskursu [...] tworzą i wprowadzają do swoich tekstów rozmaite zwroty, frazy, neologizmy, dzięki czemu wzbogacają 
dyskurs o nowe znaczenia i czynią go bardziej wyspecjalizowanym w obrębie określonego zanurzenia kulturowego" (Chruszczewski, 2011, s. 228).

Antropologiczna kreatywność przedstawicieli kultury ludowej w zakresie językowego tworzenia przestrzennych form symbolicznych (nadawania etnicznych nazw obiektom topograficznym w celu przeobrażania ich w miejsca kulturowe) odgrywa w komunikacji społecznej rolę archetypowego, mitycznego kodu źródłowego. Uniwersalną funkcję kulturową i komunikacyjną owego kodu (archetypowych historii, opowieści, komunikatów) w oddziaływaniu perswazyjnym opisał Kent Wertime (Wertime, 2002, ss. 44, 55, 59-69). W opinii Wertime’a zrozumienie archaicznych wzorów mitycznych zapewnia kreowanie efektywnej komunikacji (Wertime, 2002, s. 68).

W nazwach etnicznych i związanych $\mathrm{z}$ nimi opowieściach ludowych są zakodowane archetypowe znaczenia symboliczne (prototypowe wzorce umysłowe i aksjologiczne), które pomagają na poziomie przednaukowym określać, wyjaśniać, uzasadniać określone postawy społeczne; interpretować zjawiska, stany rzeczy, dzieje danej zbiorowości; sankcjonować wartości i normy kulturowe. Antropologiczna potrzeba kreowania nazw etnicznych jako form symbolicznych do nadawania danej przestrzeni statusu „miejsca” wynika $\mathrm{z}$ fundamentalnej roli myślenia mitycznego $\mathrm{w}$ kulturze ludowej. Mityczne wzorce, zakodowane w wypowiedziach ludowych, pełnią funkcję archetypowych wskazówek w zakresie tego, jak żyć zgodnie z wartościami i normami kulturowymi danej społeczności; w jaki (kulturowo oczekiwany) sposób postępować; w jaki (akceptowany społecznie) sposób myśleć; jakiego dobra pożądać (do jakich wartości dodatnich dążyć); jakiego zła się wystrzegać (jakich wartości ujemnych unikać). Nazwy etniczne jako elementy symboliczne i mityczne (utrwalane w ludowych legendach, historiach przekazywanych międzypokoleniowo, opowieściach, wypowiedziach respondenckich) mobilizują aktywność kulturową w zakresie kreowania, aktualizowania legendarnych historii w antropologicznych sytuacjach spotkania, rozmowy, wywiadu w zdarzeniach komunikacyjnych.

Bibliografia

Anusiewicz, J. (1994). Lingwistyka kulturowa: Zarys problematyki. Wrocław: Wydawnictwo UWr. Anusiewicz, J. (1995). Językoznawstwo kulturowe. Wrocław: Wydawnictwo UWr. 
Ahearn, L. M. (2013). Antropologia lingwistyczna: Wprowadzenie. Kraków: Wydawnictwo UJ.

Bartmiński, J., \& Niebrzegowska-Bartmińska, S. (2012). Tekstologia. Warszawa: Wydawnictwo Naukowe PWN.

Basso, K. H. (1996a). Wisdom sits in places: Notes on a Western Apache landscape. W: S. Feld \& K. H. Basso (Red.), Senses of place (ss. 53-90). Santa Fe, NM: School of American Research Press.

Basso, K. H. (1996b). Wisdom sits in places: Landscape and language among the Western Apache. Albuquerque: University of New Mexico Press.

Bettelheim, B. (1975). The uses of enchantment: The meaning and importance of fairy tales. New York, NY: Vintage Books, A Division of Random House.

Bettelheim, B. (1985). Cudowne i pożyteczne: O znaczeniach $i$ wartościach baśni (D. Dane, Tłum) (T. 1). Warszawa: PIW.

Briggs, C. L. (1986). Learning how to ask: A sociolinguistic appraisal of the role of the interview in social science research. Cambridge: Cambridge University Press. https://doi.org/10.1017/ CBO9781139165990

Bucholtz, M., \& Hall, K. (2008). All of above: new coalitions in sociocultural linguistics. Journal of Sociolinguistics, 12(4), 401-431. https://doi.org/10.1111/j.1467-9841.2008.00382.x

Burska-Ratajczyk, B. (2013). Realizacja funkcji perswazyjnej w tekstach gwarowych. Łódź: Wydawnictwo UŁ.

Chruszczewski, P. P. (2011). Językoznawstwo antropologiczne: Zadania i metody. Wrocław: Oddział Polskiej Akademii Nauk we Wrocławiu.

Creese, A. (2008). Linguistic ethnography. W: K. A. King \& N. H. Hornberger (Red.), Encyclopedia of language and education: T. 10. Research methods in language education (2. wyd., ss. 229-241). New York, NY: Springer. https://doi.org/10.1007/978-0-387-30424-3_257

van Dijk, T. A. (1980). Text and context: Explorations in the semantics and pragmatics of discourse. London: Longman.

Drowdwiłło-Batura, I. (2007). Relikty kultury tradycyjnej w świadomości mieszkańców powiatu augustowskiego w końcu XX wieku: Nazewnictwo, duchy, strachy, zwidy, lecznictwo. Rocznik Augustowsko-Suwalski, 7, 109-144.

Duranti, A. (1997). Linguistic anthropology. Cambridge: Cambridge University Press. https:// doi.org/10.1017/CBO9780511810190

Eliade, M. (1993). Traktat o historii religii (J. W. Kowalski, Tłum.). Łódź: Opus.

Filar, D., \& Piekarczyk, D. (2006). Językowo-kulturowy kontekst tekstu. W: J. Mazur \& M. Rzeszutko-Iwan (Red.), Teksty kultury: Oblicza komunikacji XXI wieku (ss. 21-33). Lublin: Wydawnictwo UMC.

Foley, W. A. (1997). Anthropological linguistics: An introduction. Malden, MA: Blackwell Publishing.

Fromm, E. (1994). Zapomniany język: Wstęp do rozumienia snów, baśni i mitów (J. Marzęcki, Tłum.). Warszawa: PIW. 
Griniewicz, S., Zaniewski, J., Skopiuk, T., \& Sorokina, E. (2009). Antropologia lingwistyczna (nowa nauka XXI wieku). Białystok: Wydawnictwo WSFiZ w Białymstoku.

Hanks, W. F. (1996). Language and communicative practices. Boulder, CO: Westview.

Jung, K. G. (1993). Archetypy i symbole (J. Prokopiuk, Tłum.). Warszawa: Czytelnik.

Mieletinski, E. (1981). Poetyka mitu (J. Dancygier, Tłum.). Warszawa: PIW.

de Saussure, F. (1991). Kurs językoznawstwa ogólnego (K. Kasprzyk, Tłum.). Warszawa: PWN.

Sękowska, E. (2000). Nurt antropologiczno-kulturowy we współczesnym polskim językoznawstwie. Poradnik Jezykowy, 2000(6), 11-20.

Silverstein, M. (2006). How we look from where we stand. Journal of Linguistic Anthropology, 16(2), 269-278. https://doi.org/10.1525/jlin.2006.16.2.269

Szymczak, M. (1981). Słownik języka polskiego. Warszawa: PWN.

Trzciński, Ł. (2006). Mit bohaterski w perspektywie antropologii filozoficznej i kulturowej. Kraków: Wydawnictwo UJ.

Urbańczyk, S. (1992). Encyklopedia języka polskiego. Wrocław: Zakład Narodowy im. Ossolińskich - Wydawnictwo.

Wertime, K. (2002). Building brands \& believers: How to connect with consumers using archetypes. Singapore: John Wiley \& Sons (Asia).

Zentella, A. C. (1996). The „chiquitification” of USA Latinos and their languages: or, why we need an anthropological linguistics. W: R. Ide, R. Parker, \& Y. Sunaoshi (Red.), Proceedings of the Third Annual Symposium About Language and Society, Austin [SALSA]. Texas Linguistic Forum 36 (ss. 1-18). Austin: University of Texas Department of Linguistics.

\section{Microtoponyms as a way of creating folk cultural places - the approach of linguistic anthropology}

\section{Summary}

The paper deals with selected issues of linguistic anthropology with the purpose to examine a few theoretical assumptions of its methodology, taking into account Keith H. Basso's study on the creation of cultural places as a result of linguistic activity. The research is based on the empirical material obtained from Polish native speakers, namely, folk tales of the residents of the Augustów County. 


\section{Mikrotoponimy jako sposób kreowania ludowych miejsc kulturowych - podejście antropologii lingwistycznej}

\section{Streszczenie}

Tematyka artykułu dotyczy wybranych zagadnień antropologii lingwistycznej. Celem opracowania jest rekonesans głównych założeń metodologicznych antropologii języka z uwzględnieniem badań Keitha H. Basso z zakresu „tworzenia miejsc kulturowych" w rezultacie działalności językowej. Jako materiał empiryczny wykorzystano wypowiedzi polskich natywnych użytkowników języka - opowieści etniczne mieszkańców powiatu augustowskiego.

Keywords: linguistic anthropology; creation of cultural places; microtoponyms; language of folklore; folk tales; ethnic tales of beliefs; ethnic tales of memories

Słowa kluczowe: antropologia lingwistyczna; tworzenie miejsc kulturowych; mikrotoponimy; język folkloru; opowieści ludowe; opowieści wierzeniowe; opowieści wspomnieniowe

(1) Arkadiusz Dudziak, Department of Social Communication and Media Language, Institute of Journalism and Social Communication, University of Warmia and Mazury in Olsztyn

Correspondence: arkadiuszdudziak@interia.pl

(2) Marina V. Paiunena, Department of Foreign Languages, Faculty of Fundamentals and Humanities, Saint-Petersburg Mining University

Correspondence: payunena@mail.ru

Authors' contribution: Research concept: first author; data gathering: first and second author; data analysis: second author; creating text: first and second author.

This article was financed with the authors' own resources.

Competing interests: The authors declare that the publication of this article is not associated with any potential conflicts of interests. 